\title{
難聴・顔面神経麻痺を伴った錐体尖部類上皮腫
}

\author{
久久湊 靖・白崎 英明・志藤 文明 \\ 形浦 昭克・中村 順一*
}

\section{A Case of Congenital Epidermoid of the Petrous Apex with Progressive Unilateral Hearing Disturbance and Facial Nerve Palsy}

\author{
Yasushi Kukuminato, Hideaki Shirasaki, \\ Fumiaki Shido and Akikatsu Kataura \\ (Sapporo Medical College) \\ Jun-ichi Nakamura \\ (Nakamura Memorial Hospital)
}

Congenital epidermoid of the petrous bone is rare. In a 38-year-old male with progressive right hearing loss and facial nerve palsy, congenital epidermoid of the petrous apex was demonstrated by CT and MRI scans.

High-resolution CT showed a soft tissue mass in the right petrous apex with bone destruction and involvement of the internal auditory canal and carotid canal. MRI showed an iso-intensity signal mass in $\mathrm{T}_{1}$ weighted images (TR1000, TE40) and a highintensity signal mass in $\mathrm{T}_{2}$ weighted images (TR2000, TE80).

Comparative evaluations with CT and MRI are useful in evaluating the expansion and characteristics of epidermoids and in differentiating them from other diseases of the petrous bone.

Key words: congenital epidermoid, hearing loss, facial nerve palsy, high-resolution CT, MRI

\section{はじめに}

頭蓋内 epidermoid の発生頻度は全脳腫瘍の 約 $1 \%$ とれているが，そのほとんどは脳硬膜 由来のもので硬膜以外の由来の屯のはほとんど 報告されていない.

今回筆者らは錐体原発と思われる錐体尖部類 上皮腫の 1 例を経験したので報告する。

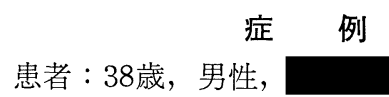

主訴：右難聴，右顔面神経麻痺.

現病歴 : 昭和50年頃より右難聴を自覚. その 後, 聴力障害は徐々に進行し昭和55年頃にはほ ぼ全龍となった。

また，昭和55年頃より右顔面神経麻痺も出現 


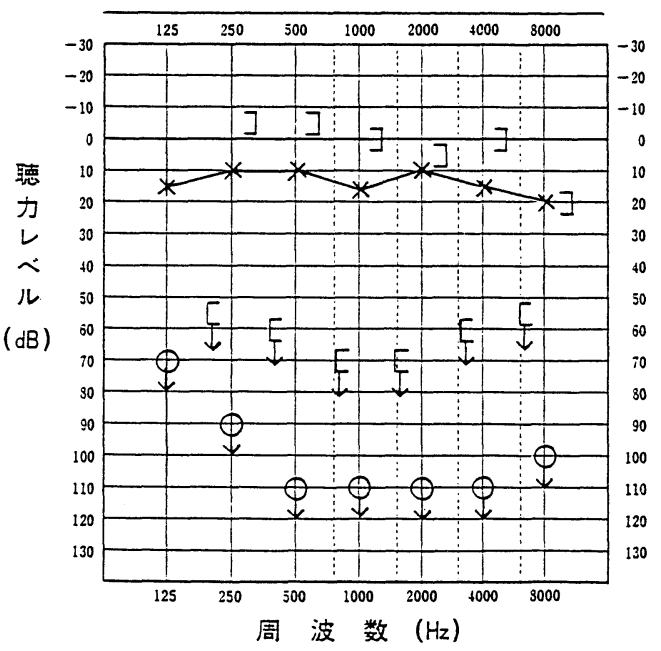

a ）純音標準聴力検査
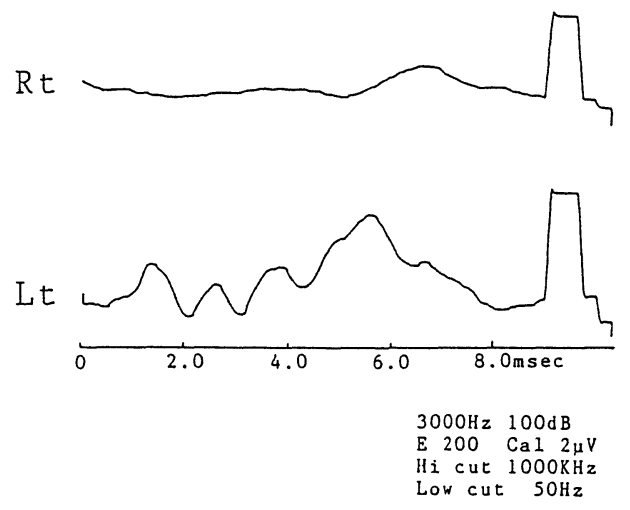

b) $\mathrm{ABR}$

\begin{tabular}{|r|c|c|c|c|c|c|c|}
\hline & \multicolumn{3}{|c|}{ CONTRA. dB HTL } & \multicolumn{3}{c|}{ IPSI. dB HTL } \\
\hline$H z$ & 500 & 1000 & 2000 & 4000 & 500 & 1000 & 2000 \\
\hline 右耳 & 120 & 120 & 120 & $S / 0$ & 100 & 100 & 100 \\
\hline 左耳 & $S / 0$ & $S / 0$ & $S / 0$ & $S / 0$ & 100 & 100 & 100 \\
\hline
\end{tabular}

$\mathrm{S} / 0$ : scale out

c）耳小骨筋反射

図 1 聴力検査

純音聴力検査で右聴力の啔失（a）をみとめ, 聴 性脳幹反応でも誘導電位の出現をみなかった（b ). 右耳の耳小骨筋反射は contra では反応がみられ なかった（c).
し，近医で右 Bell 麻痺と診断，加療されたが 軽快を認めずその後も悪化したため, 昭和62年 12月中村記念病院神経耳科を受診した.

既往歴 : 右中耳炎.

家族歷：特記すべきととなし.

初診時所見：右前額作媰・閉眼不能, 口唇の 左方偏倚と末梢性顔面神経麻痺の所見を認め麻 痺の程度は顔面神経麻痺スコア（40点法）で 6 点であった。鼓膜所見は正常で穿孔・石灰化は 認めなかった。

検査所見：純音聴力検査では右聴力の喪失を 認め, ABR む scale out であった(図 $1 \mathrm{a}, \mathrm{b}$ ).

平衡機能検査では，頭位検査で左方向水平性 眼振（困 2 ）を，温度眼振検査で右半規管麻痺 を認めたが，視運動眼振，指標追跡検査は正常 であり，中枢性異常はなかった。

顔面神経障害部位の検索では患側味覚機能の 低下および耳小骨筋反射の低下（図１c）を認 めた。

他の神経学的所見は認められなかった.

画像所見：耳レントゲン写真では右含気蜂巣 の発育不良，および右内耳道の拡大とそれに連 続した錐体骨上方の破壊を認めた (図 $3 \mathrm{a}, \mathrm{b}$ ). 内耳道断層像では蝸牛内耳道側上方まで至る骨 破壊をみるが蝸牛回転は比較的温存されており 蝸牛の破壊は明らかでない（図 $3 \mathrm{c}$ )。 また，中 耳との境界は保たれており中耳と内耳拈よび内
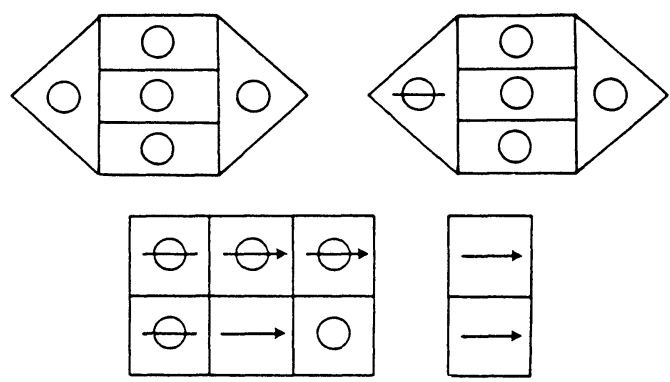

OKP ETT : 異常所見 (一)

温度眼振 : 右前庭機能廃絶

図 2 平衡機能検查

頭位および頭位変換検査で左方向水平性眼振がみ られた。 
耳道との交通はないと思われた。単純 CT では 右内耳道近傍の骨破壊と soft tissue density mass を認めたが，経静脈的造影剂投与による 陰影増強は明らかではなかった（図 $4 \mathrm{a}$ ). isovist CT により小脳橋角部への病変の進展は否 定された（図 $4 \mathrm{~b}$ ). high-resolution CT では内側には内頸動脈 岩様部まで及び，外側には蝸牛上部まで及ぶと 思われる錐体骨破壞を認めたが，半規管は正常 に保たれ，同時に中耳真珠腫を疑わせる所見は 認められなかった（図 $5 a ， b$ ).

また血管造影では，内頸動脈岩様部の圧迫所
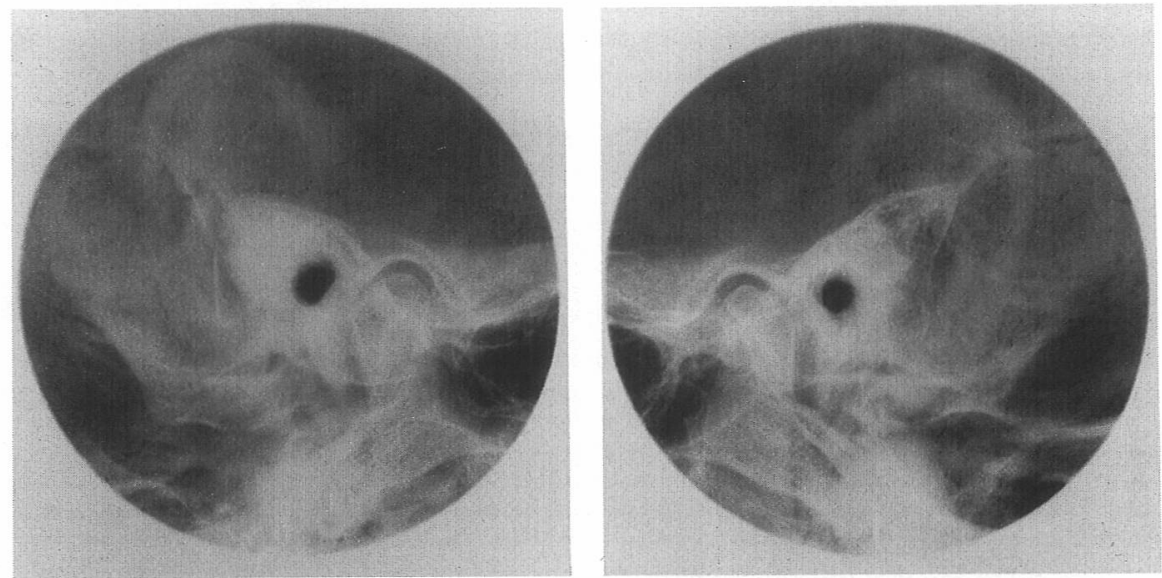

a ）シューラー氏法
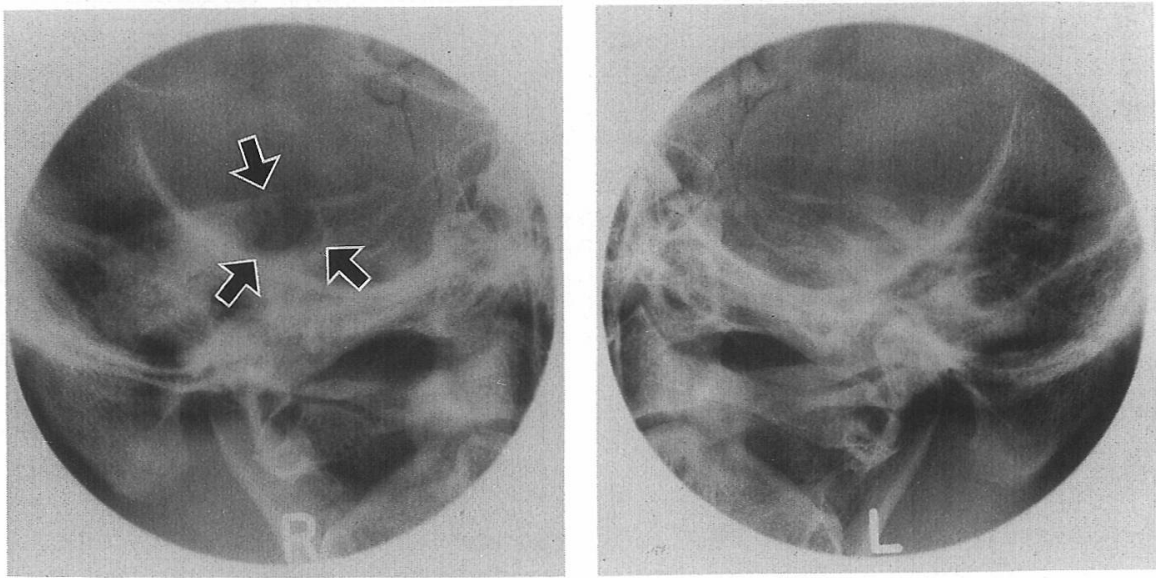

b ）ステンバー氏法

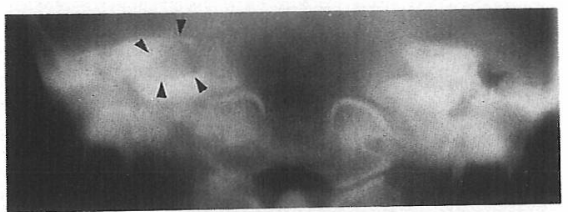

図 3 耳X線像

右耳含気蜂巣の発育不良をみとめるが, 骨融解像 はない (a). 右内耳道の拡大と, それ連続し た錐体骨上方の骨融解像がみられる（b， c一矢 印).

c）内耳道正面方向断層 
見を認めたが錐体骨破壊部位に一致しての血管 の描出はなかった。

MRI では, $\mathrm{T}_{1}$ 強調画像 (TR 1000, TE 40) で右内耳道から錐体骨にかけて存在する isointensity mass を, $\mathrm{T}_{2}$ 強調（TR 2000, TE 80) で high-intensity mass を認めたが，CT 所見 と同様，中耳，乳突蜂巣には腫瘤を示す明らか な所見はなかった（図6 $\mathrm{a} ， \mathrm{~b})$.

以上の画像診断所見加ら内耳道より錐体骨に
至る充実性腫瘍が示唆され，昭和63年 1 月中村 記念病院脳神経外科に沶いて拡大中頭蓋窩法 （慶応大変法）に準じた側頭開頭による腫瘍摘 出術が施行された。

術前検査での錐体骨破壊部位に一致し脳硬膜 に癒着した白色光沢の腫瘍をみとめた，腫瘍と 周辺組織との境界は肉眼上明瞭であり，腫瘍の 脳硬膜からの豩離は比較的容易であった。腫瘍 による錐体骨の破壞は，前上方へは内頸動脈岩
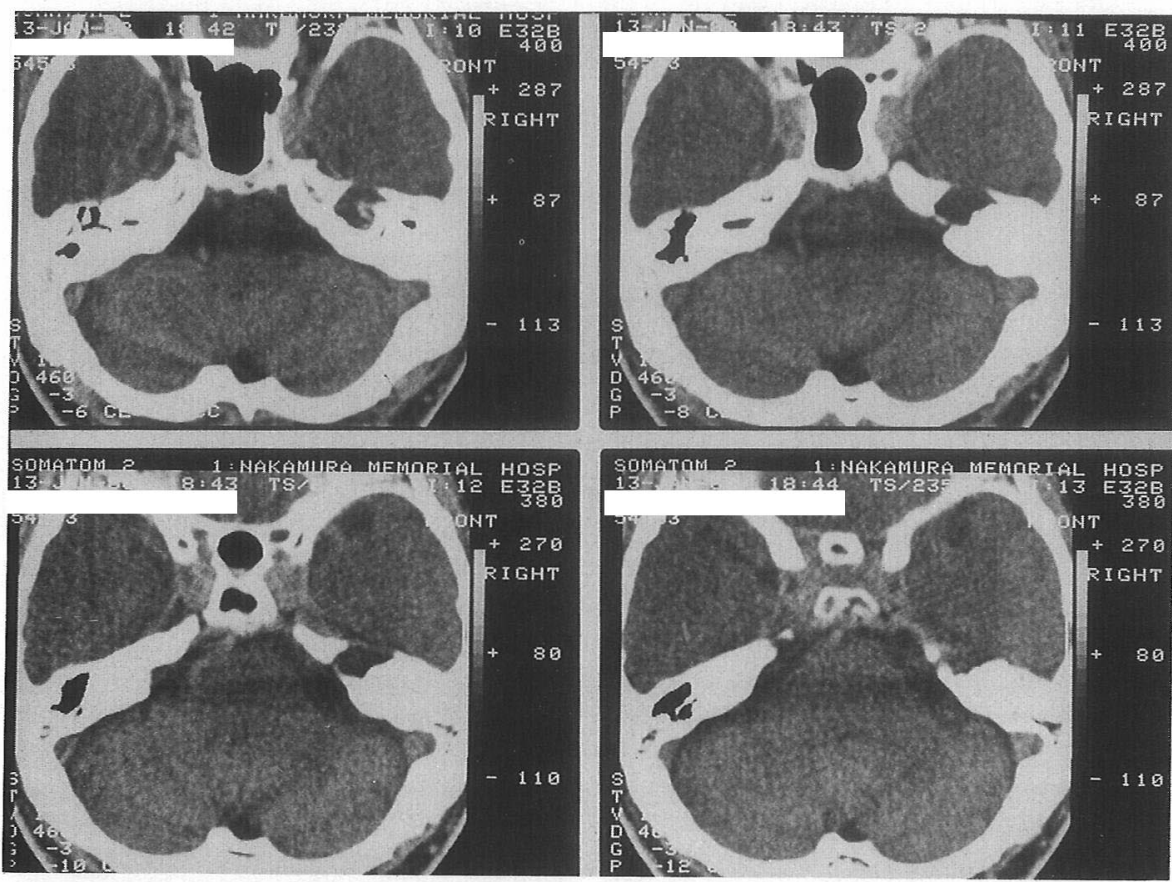

a) エンハンスメント CT

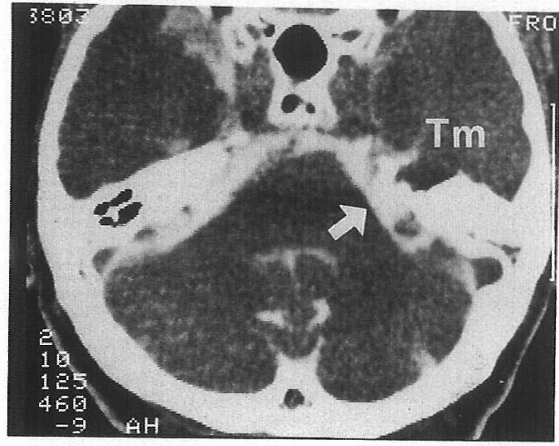

図 4 CT 像

右内耳道近傍の骨破壊之 soft tissue density mass をみとめるが，明らかな陰影増強はみとめない (a). 小脸橋角部への病変の進展もみられない ( b一矢印).

Lt $\mathrm{Rt}$

b) イソビスト $\mathrm{CT}$ 
様部まで至っており露出した内頸動脈が確認さ れ，脳血管造影上の内頸動脈圧迫部位であると 思われた。内耳道は前壁および上壁が破壊され ていたが後壁の破壤はなく，腫瘍により後方に 圧排されている第VII・VIII脳神経を確認した。肉 眼上，両神経への腫瘍の浸潤はなく，腫瘍から 容易に㓦離できたが，第VII脳神経に萎縮が認め られた。第VII脳神経には明らかな萎縮は認めら れなかった。蝸牛，半規管への腫瘍の浸潤はな く膜迷路は温存されていた。中耳とは骨皮質で 隔てられており耳管への進展むなかった。 小脳 橋角部への腫瘍の進展もなかったととから前下

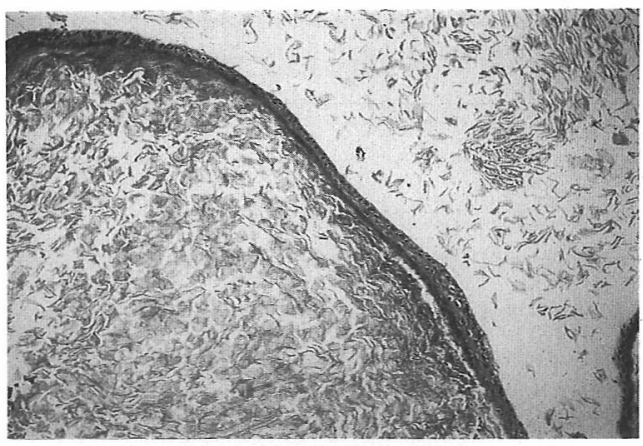

図 7 病理組織像（光顕）

病理組織学的に, 多量のケラチンと重層扁平上皮 からなる類上皮腫であるととがわかる。 a)

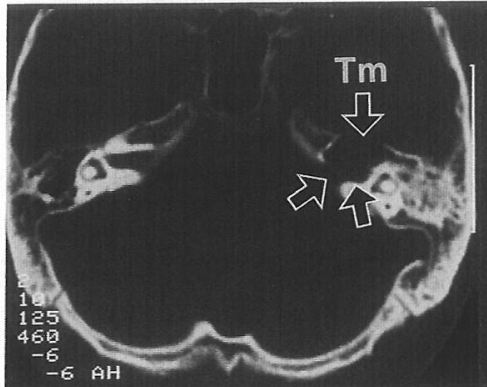

$\mathrm{Lt}$
Rt

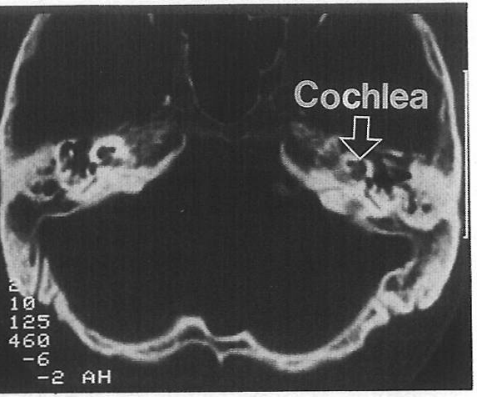

Lt b)

Rt

図 5 high-resolution $\mathrm{CT}$ 像

内耳道より内頸動脈岩様部および蝸牛上方まで及ぶと思われる錐体骨破壊をみとめる（a 一矢印） が，半規管は正常で，蟜牛屯部分的には正常と思われた（b一矢印).

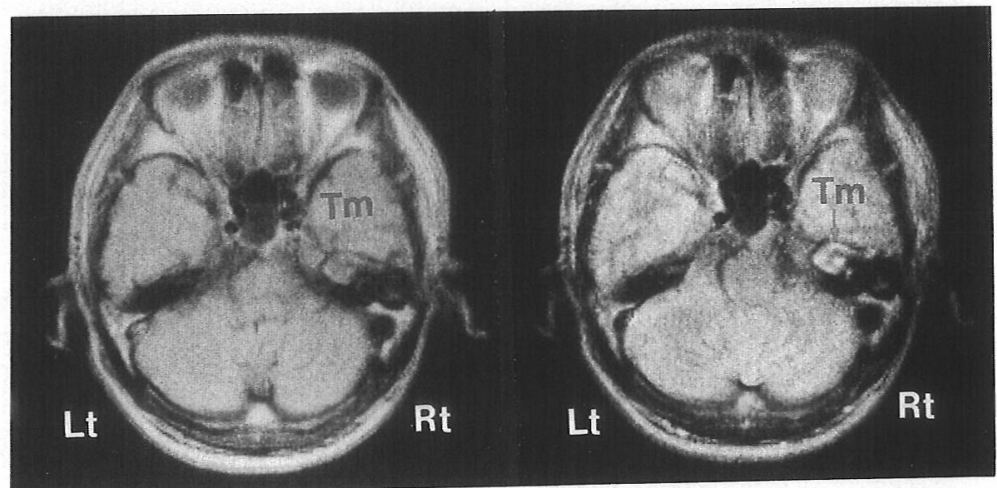

a) T1 強調像 (TR 1000, TE 40)

b) T2 強調像 (TR 2000, TE 80)

図 6 MRI 像

骨破壊部に，T $T_{1}$ 強調画像 (TR 1000, TE 40) で右内耳道から錐体骨にかけて存在する isointensity mass ( $\mathrm{a}$-矢印) を, $\mathrm{T}_{2}$ 強調 (TR 2000, TE 80) で high-intensity mass (b一矢印) をみとめ たが，CT 所見之同様，中耳，乳突蜂巣には腫瘤を示す所見はない。 
小脳動脈は正常に保たれていると考えられた。

摘出された腫瘍は病理組織学的に重層扁平上 皮とケラチンよりなる類上皮腫と診断された (図 7 ).

以上の手術時所見，病理学的所見から，本症 例は錐体尖部原発の類上皮腫之診断された。

術後，外来にて経過観察中であるが，現在の ところ難聴および顔面神経麻疾の改善は認めら れていない.

\section{考察}

頭蓋内類上皮腫は全脳腫瘍のおよそ $1 \%$ にみ られる稀な腫瘍である。そその好発部位は小脳橋 角部・傍鞍部で脳硬膜からの発生が多く，小脳 橋角部腫瘍では $6 \sim 7 \%$ の発生頻度 ${ }^{12)}$ 之言わ れているが，頭蓋板間，錐体骨などの硬膜外よ りの発生はさらに希少である.

今回筆者らの経験した錐体尖部類上皮腫は, 中耳炎既往のあることから Derlacki ${ }^{3}$ による 先天性真珠腫の定義には完全に合致しないあの の，術中所見で腫瘍は錐体尖部から内耳道に限 局し中耳との交通がなかったとと，CT，MRI で中耳内に真珠腫を認めなかったことから，幼 少時の中耳炎と錐体骨内病変との関連性はない あの之思われ，乙の点加ら本症例は硬膜外に発 生した錐体尖部先天性真珠腫と考えられる。

本邦での先天性真珠腫の報告は，大村ら ${ }^{4)}$ に よると1984年まででわずか23例であり，中でも 本症例のような錐体骨に発生した症例は滝本 ら ${ }^{5)}$ が1971年に初めて報告して以来，1987年ま でに10例を数えるのみである(677.

これら10例の主訴は，10例中 8 例が顔面神経 麻痺で，乙のいずれもが同時に聴力障害を伴っ ていたが，明らかな平衡機能障害を訴えていた 症例は 1 例のみで, 本症例屯臨床症状は進行す る顔面神経麻痺と難聴のみであり, 右半規管麻 痺にもかかわらず明らかな平衡機能障害の自覚 はなく，すでに報告されている錐体骨類上皮腫 の臨床症状の特徴288) に合致している.

本症例の場合, 腫瘍の増大に伴う長期の第 VII, VIII脳神経圧迫のため顔面神経麻痺・難聴・半規
管麻痺が生じたものと考えられるが，乙のうち 平衡機能障害の自覚がなかったととは, $\mathrm{Mafee}^{9)}$ や Gacek ${ }^{10)}$ らの指摘のように類上皮腫の増大 が緩慢であるため，乙の間に代償機能が充分働 いたためと思われる.

錐体骨内病変の鑑別すべき疾患としては表 1 に示すむのがあげられるが，乙のなかで比較的 発症頻度の高いものは顔面神経鞘腫および聴神 経鞘腫といわれ，特に顔面神経鞘腫はその好発 部位が膝部から鼓室部に多く，また臨床症状屯 顔面神経麻痺，難聴 お方よ゙平衡機能障害 ${ }^{11) ~ 13) ~}$ などのごとく共通点が多いことから腫瘍が錐体 骨に限局した症例では特に鑑別が重要と思わ れる。

診断上の鑑別点として, 小脳橋角部や中頭蓋 窩に進展した類上皮腫では，単純 $\mathrm{CT}$ 上脳脊䯣 液にほぼ等しい吸光度で陰影増強されず，また 血管造影で hypervascular 像を示さないという 画像診断上の特徽があげられる ${ }^{14)}$ 17). 本症例 のような錐体部類上皮腫の場合でもとれらとほ ぼ同様の画像診断上の特徵があり好発年齢, 臨 床経過とを考え合わせることにより他疾患との 鑑別がある程度可能とも言われるが89818), 腫 瘍自体が小さいととに加え, CT 画像では腫瘍 周辺の骨組織の artifact を受け易く, highresolution CT でも鑑別すべき他の良性腫瘍と 同様, 辺縁明瞭な骨融解を伴う soft tissue density mass として描出される ${ }^{10)}$ ため, 性状をと らえにくい点があり，CT による錐体部類上皮 腫の術前鑑別診断は小脳橋角部や中頭蓋の場合

表 1 錐体骨骨融解性病変の鑑別疾患

\begin{tabular}{l|l}
\hline \hline 一 次 性 疾 患 & 二次 性 疾 患 \\
\hline 類上皮腫 & 転移性腫瘍 \\
コレステリン肉芽腫 & 錐体炎 \\
神経鞘腫 & 脊索腫 \\
髄膜腫 & Glomus 腫瘍 \\
粘液囊胞 & 白血病 \\
骨または軟骨腫瘍 & 悪性リンパ腫 \\
脳動脈瘤 & Histiocytosis X
\end{tabular}


と比較し困難と考えられる。

今回筆者らは本症例に MRI 検査を施行し, high-resolution $\mathrm{CT} の$ soft tissue density mass が， $\mathrm{T}_{1}$ 強調画像で iso-intensity, $\mathrm{T}_{2}$ 強調で high-intensity である周辺組織と明瞭な境界を 持つ一塊の充実性腫瘍であるととを術前に知る ことができた．乙の様に MRI 検査を術前検索 に加えることにより, enhancement CT, highresolution CT および脳血管造影のみの従来の 画像診断之比較し，腫瘍占拠範囲，腫瘍の性状 および周辺組織への広がりについてより多くの 情報を得ることができたととは，他疾患との鑑 別ならびに中耳疾患との関連の有無を検討する 上で有用であった。

MRI は，骨組織の artifact がほとんどない ため錐体骨内病変や小脳・脳幹・脊髄の明瞭な 画像を描出できる，軟組織のコントラストが明 確である，またさらに，緩和時定数の変更によ り得られる画像の intensity から病変部位の内 部構造や性状を推測しうる，などの特性がある ことから，近年頭頸部領域での有用な診断法の 一つとされ $\left.{ }^{199} 20\right)$ ，錐体部類上皮腫についても CT との併用による診断の有用性を指摘した報 告が多(2) 14)2122).

類上皮腫はコレステロールや脂肪分を多く含 むため MRI 画像上の特徽として比較的短い $\mathrm{T}_{1}$ relaxation time と中程度に長い $\mathrm{T}_{2}$ relaxation time を持ち脂肪組織に似た画像となるこ とから ${ }^{1422)}, \mathrm{T}_{1}, \mathrm{~T}_{2}$ relaxation time が正常脳 実質よりも延長の傾向がある神経鞘腫などの他 疾患 20122) 23) との質的な鑑別が出来る可能性が あり，今後さらに症例を検討することで MRI による質的な鑑別の発展む期待されると思われ る.

本症例は当初 Bell 麻痺と診断されていたが， 藤原ら ${ }^{24)}$ によると末梢性顔面神経麻痺の $0.8 \%$ が腫瘍が原因であり，北條ら ${ }^{25)}$ は Bell 麻痺と 見逃されていた 9 症例中 5 例に側頭骨内腫瘍を， また 3 例に頭蓋内腫瘍を認めている．乙の点か ら末梢性顔面神経麻㿁診断時の錐体骨内病変の
検索は欠かせないものと思われ，乙の場合神経 学的検索に CT, MRI を加えた画像診断学的検 索が有用であると思われた。

\section{まとめ}

1. 徐々に進行する右聴力障害, 末梢性顔面 神経麻痺にて発症した右錐体尖部類上皮腫の一 例を経験した。

2. 䛦断に際し high-resolution CT および MRI が有用であった.

3. 画像診断所見, 手術時所見および病理組 織学的所見から先天性真珠腫と考えられた.

4. 末梢性顔面神経麻痺に打ける頭蓋内病変 の検索の重要性が強調された。

尚, 本論文の要旨は第50回耳鼻咽喉科臨床学会にて ロ演した。

\section{参考文献}

1) Revilla AG : Differential diagnosis of tumors of the cerebellopontine recess. Johns Hopkins Hosp Bull 83 : 187 211, 1947.

2) Rosenberg RA, Hammerschlag PE, Cohen NL, et al : Cholesteatoma vs. cholesterol granuloma of the petrous apex. Otolaryngol Head Neck Surg $94: 322 \sim 327,1986$.

3) Derlacki EL : Congenital cholesteatoma of the middle ear and mastoid. Ann Oto Rhino Laryng $74:$ 706 727, 1965.

4) 大村文秀, 下村友佳子, 深澤高士, 他 : 先天性真 珠腫の 1 例. 耳喉 $58: 929 \sim 933,1986$.

5 ) 滰本 勲: 稀有なる錐体部真珠腫の 2 例. 耳鼻臨 床 $64: 37 \sim 47,1971$.

6 ）行木英生, 国弘幸伸, 川浦光弘, 他 : 錐体部型先 天性真珠腫の 1 症例と有茎胸鎖乳突筋弁による術 後欠損腔充填術の経験. 臨床耳科 $13: 254 \sim 255$, 1986.

7 ) 太田和博, 松永 喬, 森 望: 慢性中耳炎を伴 った側頭骨類上皮腫の一例. 臨床耳科 $13: 376$ 377, 1986.

8) Cawthorne $\mathrm{T}$ and Griffith A: Primary cholesteatoma of the temporal bone. Arch Otolaryngol $73:$ 252 261, 1961.

9) Mafee MF, Aimi K and Valvassori GE : Com- 
puted tomography in the diagnosis of primary tumors of the petrous bone. Laryngoscope 94 : 1423 1430, 1984.

10) Gacek RR : Evaluation and management of primary petrous apex cholesteatoma. Otolaryngol Head and Neck Surg 88 : 519 523, 1980.

11) Lipkin FA, Coker NJ, Jenkins HA, et al : Intracranial and intratemporal facial neurinoma. Otolaryngol Head and Neck Surg 96:71 79, 1987.

12）市川昭道, 田中隆一，松村健一郎，他：中頭蓋窩 に発育・進展した顔面神経鞘腫の 3 例. CT 研究 $8: 209 \sim 218,1986$.

13）板垣晋一, 山田潔忠, 川上千之, 他 : Crocodile tear syndrome を伴った顔面神経鞘腫の 1 例. Neurol Med Chir (Tokyo) $26: 807 \sim 810,1986$.

14) Latack JT, Kartush JM, Kemink JL, et al : Epidermoidomas of the cerebellopontine angle and temporal bone; CT and MR aspects. Radiology $157:$ 361 366, 1985.

15）宮崎紳一郎，福島孝德：Hemifacial spasm で発 見された CT angle epidermoid. 脳神経 35： 951 955, 1983.

16）石黒修一，木村 明，宋本 滋，他：側頭骨に発 生し, 腫瘍内出血を認めた巨大 Diploic epidermoid の 1 例. 脳神経外科 $13: 445 \sim 449,1985$.

17) Olson JJ, Beck DW, Crawford SC, et al : Comparative evaluation of intracranial epidermoid tumors with computed tomography and magnetic resonance imaging. Neurosurgery 21 : 357 360, 1987.
18) Lo WWM, Solti-Bohman LG, Brackmann DE, et al: Cholesterol granuloma of the petrous apex; CT diagnosis. Head Neck Surg 153 : 705 711, 1984.

19）野村公寿：耳鼻咽喉科・頭頸部領域における MRI の臨床応用. 耳喉 59 : 549 555， 1987.

20) Baker SR and Latack JT : Magnetic resonance imaging of the head and neck. Otolaryngol Head Neck Surg 95:82 89, 1986.

21) Maslan MJ, Latack JT, Kemink JL, et al : Magnetic resonance imaging of temporal bone and cerebellopontine angle lesions. Arch Otolaryngol Head and Neck Surg $112: 410 \sim 415$, 1986.

22) Koenig H, Lentz $M$ and Sauter $R$ : Temporal bone region; High-resolution MR imaging using surface coils. Radiology $159: 191 \sim 194$, 1986.

23) Griffin C, DeLaPaz R and Enzmann D : MR and CT correlation of cholesterol cysts of the petrous bone. AJNR 8:825 829, 1986.

24）藤原 享：末梢性顔面神経麻痺症例の統計的観 察. Facial N Res Jpn 1:27〜30, 1986.

25）北條和博, 遠藤泰介, 村松良雄, 他：Bell 麻痺之 見過ごされていた 9 症例.耳鼻臨床 $80: 1515$ 1520, 1987.

$\left(\begin{array}{l}\text { 原稿採択 : 平成元年 } 4 \text { 月 } 13 \text { 日 } \\ \text { 別刷請求先 : 久々湊靖 } \\ \text { T060 札幌市中央区南 } 1 \text { 条西 } 16 \text { 丁目 } \\ \text { 札幌医科大学耳鼻咽喉科学教室 }\end{array}\right)$

